\title{
DIAGNOSING HUMAN PAPILLOMAVIRUS AND HUMAN PAPILLOMAVIRUS TYPE 16 BY REALTIME PCR IN PATIENT UNDERGONE TO COLPOSCOPY AND SIGNIFICANCE OF THE DIAGNOSIS
}

\author{
Sibel OZDAS ${ }^{1}$, Gulendam BOZDAYI ${ }^{1}$, Aytul DEMIRAG ${ }^{1}$, Anil ONAN² ${ }^{2}$,agatay TASKIRAN ${ }^{2}$, Mustafa N. ILHAN ${ }^{3}$ \\ 1 Department of Medical Microbiology, Gazi University, Faculty of Medicine, Ankara \\ 2 Department of Obstetrics and Gynecology, Gazi University, Faculty of Medicine, Ankara \\ 3 Department of Public Health, Gazi University, Faculty of Medicine, Ankara
}

\begin{abstract}
SUMMARY
Objective: It is aimed to determine presence of HPV and HPV 16 by Real-Time PCR in cervical smears obtained from patients during colposcopic examination who had referred to outpatient clinic of Gynecology and Obstetrics Department due to various complaints and to examine interrelation between positive test results and clinical data.

Material and methods: Sixty patients were included in the study who were referred to outpatient clinic due to varied complaints and who had been decided to undergo colposcopic examination. DNA was obtained from each smear sample by phenol-chloroform-isoamylalcohol method. L1 region was amplified in amplification process using MY09/MY11 primers. Products for Nested Real time PCR were studied in Light Cycler by GP5+/GP6+ primers and Cyanine-5 labeled HPV 16 DNA specific probe. Real time PCR products underwent melting curve analysis by LightCycler software version 3.5.3. HPV DNA positivity and HPV 16 positivity were determined at $78-82^{\circ} \mathrm{C}$ and $68^{\circ} \mathrm{C}$, respectively.

Results: No statistically significant difference could be detected between HPV positivity, HPV 16 and types other than HPV 16 in control group and patients with positive test result as a consequence of colposcopic examination. Again, no statistically significant difference could be detected between HPV positivity and status of parity, PAP test result, marital status and age of patient.

Conclusion: No statistically significant difference could be detected between HPV positivity, HPV 16 and types other than HPV 16 in control group and patients with positive test result as a consequence of colposcopic examination. Again, no statistically difference could be detected between HPV positivity and result of PAP smear test, marital status, age of patient and smoking but statistically significant difference could be detected between types other than HPV 16 and status of parity (respectively; $\chi^{2}=0.821, p=0.365 ; \chi^{2}=0.752, p=0.564 ; \chi^{2}=0.364, p=0.834 ; \chi^{2}=6.835$, $p=0.033)$.
\end{abstract}

Key words: cervical cancer, coloscopy, HPV, Real-Time PCR, risk factors

Journal of Turkish Society of Obstetrics and Gynecology, (J Turk Soc Obstet Gynecol), 2013; Vol: 10, Issue: 2, Pages: $79-89$

\footnotetext{
Address for Correspondence: Dr. Gulendam Bozdayi. Gazi Üniversitesi Tıp Fakültesi, Tıbbi Mikrobiyoloji Anabilim Dalı, Beşevler, Ankara Phone: +90 (505) 5118947

e-mail: gbozdayi@hotmail.com

Received: 12 July 2012, revised: 12 July 2012, accepted: 14 November 2012, online publication: 15 November 2012
} 


\title{
KOLPOSKOPİ UYGULANAN HASTALARDA REAL- TIME PCR İLE HUMAN PAPILLOMAVIRUS VE HUMAN PAPILLOMAVIRUS TIP 16 TANISI VE ÖNEMİ
}

ÖZET

\begin{abstract}
Amaç: Kadın Hastalıkları ve Doğum Anabilim Dalı polikliniğe çeşitli nedenlerle başvuran hastaların kolposkopik muayenesi sirasinda alınan serviks sürüntü örneklerinde Real-Time PCR ile HPV ve HPV tip 16 varlğgın saptanması ve klinik veriler ile pozitiflik arasındaki iliş̧kiyi irdelemek amaç lanmıştır.
\end{abstract}

Gereç ve yöntemler: Çalışmaya, disüri, vajinal akıntı, bel ve kasık ağrısı, postkoital kanama şikâyetleriyle polikliniğe başvuran, kolposkopi karart verilen ve servikal sürüntü örneği alınan 60 hasta dahil edilmişstir. Sürüntü örneklerinden fenol-kloroform-izoamilalkol yöntemi ile DNA elde edilmiștir. Amplifikasyonda MY09/MY11 primerleri kullanilarak $L 1$ bölgesi çoğalttlmiştır. Nested Real-Time PCR iç in MY09/11 ürünleri GP5+/GP6+ primerleri ve Cyanine-5 labeled HPV 16 DNA specific probe ile Ligth Cycler (Roche Diagnostics, Germany) cihazında çalıșllmıștır. Real time PCR ürünlerine, LigthCycler software version 3.5.3 (LC 2.0 Roche Diagnostics, Germany) programı ile melting curve analizi yapılmuştır. Human papillomavirus DNA pozitifliği $78-82^{\circ} \mathrm{C}^{\prime} d e, H P V 16$ pozitifliği ise $68^{\circ} \mathrm{C}^{\prime}$ de tespit edilmiştir. Bulgular: Kolposkopik inceleme sonucu pozitif bulgusu olan hastalarda ve kontrol grubunda HPV pozitifliği, HPV tip 16 ve HPV 16 dlşsındaki tipler arasinda istatistiksel olarak anlaml bir fark tespit edilememişstir $(\chi 2=1.981 p=0.371$; $\chi^{2}=1.524 p=0.467 ; \chi^{2}=3.644 p=0.162$ ). HPV pozitifliği ile PAP smear testi sonucu, medeni durum, yaş ve sigara arasında istatistiksel olarak anlamlı bir fark bulunamamışken, HPV 16 dışındaki tipler ile gebelik sayısı arasında istatistiksel olarak anlamlı bir fark tespit edilmişstir (sırasıyla; $\chi^{2}=0.821, p=0.365 ; \chi^{2}=0.752, \quad p=0.564 ; \chi^{2}=0.364$, $p=0.834 ; \chi^{2}=6.835, p=0.033$.

Sonuç: Serviks kanserinde en önemli etkenlerden kabul edilen Human papillomavirus tanısı günümüzde oldukça önem taşımaktadır. Çalıșmamızda kolposkopik bulgular ile HPV prevalansı arasında istatistikî anlam taşıyan bir iliş̧ki bulunmuștur. Real Time PCR yöntemi ile kolposkopi pozitif bulunan hastaların, belli bir algoritma dâhilinde takiplerinin yapılması ve sonuç lar doğrultusunda hastaların yönlendirilmesinin önemli olduğunu düşünmekteyiz.

Anahtar kelimeler: HPV, kolposkopi, Real-Time PCR, risk faktörleri, servikal kanser

Türk Jinekoloji ve Obstetrik Derneği Dergisi, (J Turk Soc Obstet Gynecol), 2013; Cilt: 10, Sayl: 2, Sayfa: 79- 89

\section{INTRODUCTION}

Cervical cancer which affects 530000 new cases every year, ranked as the second most common cancer type and it is the leading cause of cancer-related death among women ages $14-44^{(1,2)}$. Cervical cancer independent risk factors such as, sex at an early age (16), number of sex partners, tobacco use, high parity, race, age, genetic susceptibility, use of oral contraceptives and low socioeconomic status are known to have contributed to carcinogenic processes ${ }^{(1)}$. Epidemiological studies shows that especially HPV type 16 and HPV type 18 have been found to cause cervical cancer ${ }^{(1-4)}$.

Human papillomavirus (HPV), which is a member of Papillomavirinae (papillomaviridae) subfamily, is a small, non-enveloped, icosahedral virus that has doublestranded circular DNA within a nucleocapsid. Over 200 types of HPV are identified(5). HPV infections show varied clinical presentations changing from simple lesions to neoplasms. These viruses are classified in three groups as high-risk, probably high-risk and lowrisk according to the infection they have formed ${ }^{(6)}$. People having ASCUS or HSIL-LSIL lesions, formed by HPV type 16, should be followed regularly due to having high risk of developing cervical cancer. Although with cytological screening programs done with PAP smears, a distinct decrease of cancer cases and mortality is obtained, satisfactory success cannot be achieved due to about $5 \%$ of abnormal results ${ }^{(7)}$. Diagnosis and treatment of HPV infections has a big importance for protection from cervical cancer and decreasing mortality rate. For diagnosing and determining the types of HPV infections, different methods were developed. Inadequacy of newly developed immunological tests, difficulty of in vitro culture applications, problems regarding preparations and interpretation of Pap smear test samples, low 
sensitivity of cytological tests are the reasons that these tests are insufficient for diagnosing HPV infections and types and therefore microbiological diagnosis methods that can show directly HPV DNA have gained importance(7-10).

Molecular methods such as Real-Time PCR, Linear Array, Amplicor and Hybrid capture II are currently the most effective ones in studying HPV DNA. Especially when compared to traditional methods, Real-Time PCR is one of the most valid methods by minimum contamination, having no need for additional screening processes, having more than one step in amplification phase and having high sensitivity. Although they have low specificity in determining HPV DNA, molecular methods-with their high sensitivity- are used as gold standards for cervical cancer screening programs $(9,10)$.

Determining HPV DNA is very important in especially asymptomatic and occasionally disappearing HPV infections, diagnosing primer lesions and cervical cancers, following treatment of infections and early diagnosis. This study is aimed to evaluate the correlation of HPV and HPV type 16 frequencies which determined by Real time PCR and risk factors that are thought to have role in cervical cancer development in patients that have indications for colposcopy in our hospital.

\section{MATERIAL AND METHODS}

Patients: Patients who were referred to our outpatient clinic of Gazi University Medical Faculty Gynecology and Obstetrics Department between March-June 2006 with an indication of Colposcopy were included in this study. 60 Patients (ages 18-66; mean age 38 SD: 13.35) that had referred to our hospital with various complaints (dysuria, increased vaginal discharge, pain in the waist and groin, postcoidal bleeding) and had been decided to undergo colposcopic examination were included in this study. 20 patients (ages 22-55 ; mean age $37.8 \pm \mathrm{SD}: 10.53)$ without any complaints that referred to our hospital for routine control had been included in study as a control group.

In colposcopic examination, after the application of acetic acid, the patients having punctuation, mosaic or atypical vessels in cervical epithelium were classified as colposcopy positive and the patients that had normal findings were classified as colposcopy negative patients.
Every patient that had colposcopic examination, also had been screened with Pap smear tests and HPV presence correlation with age, number of parity, marital status, tobacco use were evaluated. Cervical smear samples were taken into tubes containing 3-5 ml sterile phosphate buffered saline (PBS) solutions during colposcopic examination before acetic acid application. After been sent into molecular diagnostic laboratory, all samples were vortexed and taken into $1,5 \mathrm{ml}$ Eppendorf tubes and stored at $-86^{\circ} \mathrm{C}$ until DNA purification.

DNA purification: Cells from cervical smear samples were lysed by $20 \mathrm{mg} / \mathrm{ml}$ proteinase $\mathrm{K}$ addition and by incubation first at $55^{\circ} \mathrm{C}$ for 3 hours then at $95^{\circ} \mathrm{C}$ for 10 minutes. After that, phenol-chloroformisoamylalcohol is used for DNA purification. Finally DNA was stored in sterile distilled water at $-86^{\circ} \mathrm{C}$ until amplification.

DNA Amplification: For HPV type 16 and HPV positivity analysis nested Real-Time PCR was used. MY09/MY11 primers(5'-CGTCCMARRGGAWACTGATC3), (5'-CMCAGGGWCATAAYAATGG-3) (T1b Molbiol, Germany) which are specific to L1 region that are common for most of HPV genotype were used for DNA amplification. For nested Real-Time PCR samples from MY09/11 amplification were amplified with GP5+/GP6+ primers and Cyanine-5 labeled HPV type 16 DNA specific probe [Primer F 5' TTtGTtactgtgGtagataCtAC 3', Primer R 5' GAAAAATAAACTGTAAATCATATTC 3', Cy5.0 signal probe 5'Cy5- GTTTCTGAAGTAGATATGGCAGCACAbiotin 3'(T1b Molbiol, Germany)] in Light Cycler 2.0 (Roche Diagnostics, Germany). LightCycler software version 3.5.3 (LC 2.0 Roche Diagnostics, Germany) was used for melting curve analysis. Melting peaks between $78-82^{\circ} \mathrm{C}$ showed the detection of Human papillomavirus DNA in samples whereas melting peaks about $68^{\circ} \mathrm{C}$ showed HPV type 16 DNA in samples. Results were evaluated according to these peaks. Statistics: Fisher's chi square test and Yate's correction for continuity were used for statistical analysis of data. Ethical committee approval: Research proposal was evaluated for ethical aspects and approved by Gazi University Medical Faculty Ethical Board. Before any medical treatment, patients were informed about research and processes and samples were obtained after their approvals were taken. 


\section{RESULTS}

30 colposcopy positive patients (ages 18-66; mean age $38.7 \pm$ SD: 14.6) who referred to our clinic with complaints such as dysuria, vaginal discharge, pain in the waist and groin, postcoidal bleeding, with suspicious colposcopic findings and 30 colposcopy negative patients (ages 19-66; mean age $37.5 \pm \mathrm{SD}$ : 11.45 ) with normal colposcopic examination findings were included in this study. In our study, 30\% of colposcopic positive patients were found to be HPV positive and $44.4 \%$ of these had HPV type 16 and $55.5 \%$ had different HPV types . 70\% was HPV negative. In colposcopy negative patients $13.3 \%$ were HPV positive and $50 \%$ of them had HPV type 16 and 50\% had different types of HPV. $86.6 \%$ were HPV negatives. In control group 35\% of patients were HPV positive and $57 \%$ of them had HPV type 16 , and about $43 \%$ had other types of HPV, $65 \%$ of the control group was HPV negative. When colposcopic patients were compared with control group with respect to HPV positivity and HPV type 16, no statistically meaningful difference was determined. $(\chi$ $2=1.981 \mathrm{p}=0.371 ; \chi 2=1.524 \mathrm{p}=0.467 ; \chi^{2}=3.644$ $\mathrm{p}=0.162)($ Table I).

Patients were classified in two groups due to Pap smear test result as normal or abnormal cervical cytology. Out of 43 patients (54\%) that had abnormal cervical cytology, $30.2 \%$ was HPV positive, $54 \%$ of these positive patients had HPV type 16 and $46 \%$ had other types of HPV. $69.8 \%$ was HPV negative. Out of 37 $(46 \%)$ patients that have normal cervical cytology, $18.9 \%$ was HPV positive, $43 \%$ of these patients had HPV type 16 and $57 \%$ of them other types of HPV. $81.1 \%$ of the patients were HPV negative. Pap smear test result was compared with HPV and HPV type 16 positivity and no statistically meaningful difference was found. $(\chi 2=0.821, p=0.365 ; p=0.326)$ (Tabel II).

By evaluating Pap smear test results, cases that found to be having abnormal cervical cytology were grouped according to Bethesda system. Among the women having abnormal cervical cytology, ASC-US was determined in $48.8 \%$ of them, ASC-H in $25.5 \%$, LSIL in $13.9 \%$, HSIL in $9.3 \%$ and AGUS in $2.3 \% .23 \%$ of ASC-US cases were HPV DNA positive and none of them $(0 \%)$ had HPV type $16.23 \%$ of the ASC-H cases were HPV

Table I: Variation of HPV DNA presence due to colposcopic findings.

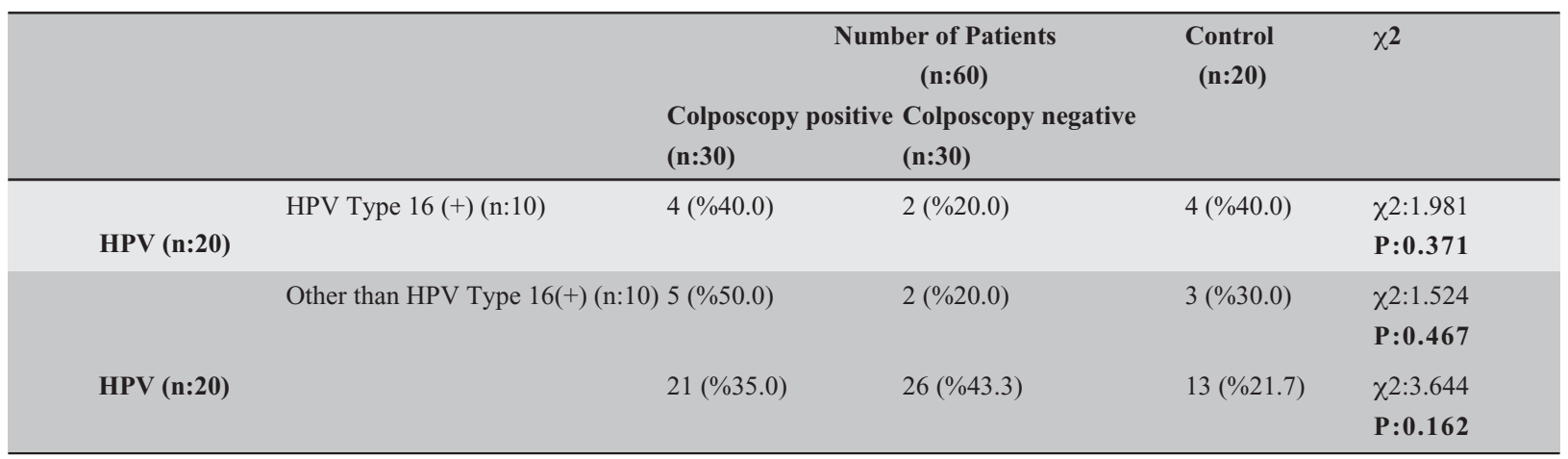

Table II: Variation of HPV DNA presence due to Pap smear results and number of pregnancies.

\begin{tabular}{|c|c|c|c|c|}
\hline Number of patients (n:80) & $\begin{array}{l}\text { HPV Type } 16(+) \\
(n: 10) n \%\end{array}$ & $\begin{array}{l}\text { Other HPV Types } \\
(+)(n: 10) n \%\end{array}$ & $\begin{array}{l}\text { Total HPV (+) (n:20) } \\
\text { n \% }\end{array}$ & $\begin{array}{l}\text { Total HPV(-) (n:60) (n:10) } \\
\text { n \% }\end{array}$ \\
\hline \multicolumn{5}{|l|}{ Pap smear } \\
\hline Normal cervial aytology (n:37) & $3(\% 8.1)$ & $4(\% 10.8)$ & $7(\% 18.9)$ & $30(\% 81.1)$ \\
\hline Abnormal cervical cytology $(n: 43)$ & $7(\% 16.3)$ & $6(\% 14.0)$ & $13(\% 30.2)$ & $30(\% 69.8)$ \\
\hline$\chi^{2}$ & $\mathrm{p}=0.326^{\mathrm{a}}$ & $\mathrm{p}=0.745^{\mathrm{a}}$ & $\mathrm{p}=0.365^{\mathrm{b}}$ & \\
\hline \multicolumn{5}{|l|}{ Number of pregnancies } \\
\hline 0-2 pregnancies (n:53) & $8(\% 15.1)$ & $4(\% 7.5)$ & $12(\% 22.6)$ & $41(\% 77.4)$ \\
\hline 3-5 pregnancies (n:23) & $2(\% 8.7)$ & $4(\% 17.4)$ & $6(\% 26.1)$ & $17(\% 73.9)$ \\
\hline 6-10 pregnancies $(n: 4)$ & $0(\% 0.0)$ & $2(\% 50.0)$ & $2(\% 50.0)$ & $2(\% 50.0)$ \\
\hline$x^{2}$ & $\mathrm{p}=0.548$ & $\mathrm{p}=0.033$ & $\mathrm{p}=0.471$ & \\
\hline
\end{tabular}

\footnotetext{
a: Fisher's exact test

b. Yates chi square correction
} 
DNA positive and $14.2 \%$ had HPV type $16.15 .4 \%$ of LSIL cases were HPV DNA positive and $28.6 \%$ of them had HPV type 16. $30.7 \%$ of HSIL cases were HPV DNA positive and $57.1 \%$ were HPV type $16.7 .8 \%$ of AG-US cases were HPV DNA positive and none of them $(0 \%)$ had HPV type 16 . (Table III).

Women included in our study were classified in three groups according to their ages as 34 and below, 35-48 and 49 and over. In the first group which consist of cases aged 34 and below, out of 31 women, $25.8 \%$ was found to be HPV positive, $\% 50$ of the positive cases had HPV type 16 and 50\% had other types of HPV. $74.2 \%$ of the women were HPV negative. In the second group which consists of cases aged 35-48, out of 30 women $23.3 \%$ found to be HPV positive and $43 \%$ of the positive cases had HPV type 16 and 57\% of them had other types of HPV. 76.7\% of the cases were HPV negative. In the third group which consists of cases aged 49 or above, out of 19 women $26.3 \%$ was HPV positive and $60 \%$ of them had HPV type 16 and $43 \%$ of them had other types of HPV. $73.7 \%$ of the cases were HPV negative. There was no statistically significant result found when age was compared with HPV positivity and HPV type 16 presence $(\chi 2=$ $0.073, \mathrm{p}=0.964 ; \chi 2=0.364, \mathrm{p}=0.834 ; \chi 2=0.091$, $\mathrm{p}=0.955)$. Three of the patients that were included into study were from control group and 2 of them were smokers. All of the smokers both in patient and control group were found to be HPV positive. There was no statistically significant difference found due to the low number of smoking patient group.

Cases that are included in our study were grouped into two classes due to their marital status as married and single. $27 \%$ of the 58 married patients were HPV positive and $50 \%$ of the positive cases had HPV type 16 and $\% 50$ had other type of HPV. $72.4 \%$ of this group were HPV negative. Out of 22 single patient, $18.2 \%$ were HPV positive and $50 \%$ of the positive cases had HPV type 16 and 50\% had other types of HPV. $81.8 \%$ of the patients in this group were HPV negative. When marital status of the patients were compared with the HPV type 16 and HPV positivity no statistically significant result was obtained $(\chi$ $2=0.752, p=0.564 ; p=0.719 ; p=0.719$ ).

In our study women were also classified according to number of pregnancies they had, such as $0-2,3-5$ and 6-10. In the 0-2 group out of 53 women $22.6 \%$ were HPV positive and $67 \%$ of the positive cases had HPV type 16 and $33 \%$ of them had other types of HPV. $77.4 \%$ were found to be HPV negative. In the 3-5 pregnancy group among 23 women $26.1 \%$ were HPV positive and $33.3 \%$ of the positive cases had HPV type 16 and $66.7 \%$ of the cases had other types of HPV. $73.9 \%$ of the cases in this group were HPV free. In the 6-10 pregnancies group among 4 women $50 \%$ of the cases were HPV positive and there were no HPV type 16 found in this group. All of the positive cases (100\%) had other types of HPV. 50\% of the cases in this group were HPV negative. Numbers of pregnancies were wanted to be compared with HPV and HPV type 16 positivity, however due to 0 values found in the lines, it could not be statistically analyzed. Meaningful relationship was determined between other types of HPV and number of pregnancies. $(\chi 2=1.505, \mathrm{p}=0.471$; $\chi 2=1.202, \mathrm{p}=0.548 ; \chi 2=6.835, \mathrm{p}=0.033)$. However, general total of HPV positivity were found to be proportionally increased with number of pregnancies. (Table II).

\section{DISCUSSION}

Early diagnosis and patient follow up are highly important in observation of HPV infections. Aim of the developing health policy should include HPV DNA determination with the help of a reachable screening

Table III: Variation of HPV DNA presence due to abnormal cervical smear results.

\begin{tabular}{|c|c|c|c|c|}
\hline & $\begin{array}{l}\text { Abnormal cervical cytology } \\
\qquad \begin{array}{c}\text { (n:47) } \\
n \%\end{array}\end{array}$ & $\begin{array}{l}\text { HPV Type } 16(+) \\
\text { (n:7) } \\
\text { n \% }\end{array}$ & $\begin{array}{l}\text { None HPV } 16 \text { Types } \\
\qquad \begin{array}{c}(+)(n: 6) \\
n \%\end{array}\end{array}$ & $\begin{array}{c}\text { Total HPV } \\
(+)(n: 13) \\
\text { n } \%\end{array}$ \\
\hline ASC-US & $21(\% 48.8)$ & $0(\% 0)$ & $3(\% 50)$ & $3(\% 23)$ \\
\hline ASC-H & $11(\% 25.5)$ & $1(\% 14.2)$ & $2(\% 33.3)$ & $3(\% 23)$ \\
\hline LSIL & $6(\% 13.9)$ & $2(\% 28.6)$ & $0(\% 0)$ & $2(\% 15.4)$ \\
\hline HSIL & $4(\% 9.3)$ & $4(\% 57.1)$ & $0(\% 0)$ & $4(\% 30.7)$ \\
\hline AG-US & $1(\% 2.3)$ & $0(\% 0)$ & $1(\% 16.6)$ & $1(\% 7.8)$ \\
\hline
\end{tabular}


program and prophylactic vaccination. Molecular methods with their high sensitivity in HPV typing are used as golden standards for cervical cancer screening $\operatorname{programs}^{(9,10)}$.

In a meta-analysis study, done by Bosch et al. 14,595 women with cervical cancer from 56 countries were included and $87.2 \%$ of them had HPV DNA. $54.4 \%$ of the HPV DNA positives had HPV type 16 and $15.8 \%$ had HPV type 18 . They reported that $10 \%$ of the women with normal cytology had HPV infection also the most common genotype was HPV type 16 and this type was responsible for $50-55 \%$ of cervical cancers. In HSIL cases, HPV general prevalence was $84.9 \%$ whereas in HSIL cases HPV type 16 prevalence was $51.8 \%$ in Europe $33.7 \%$ in Asia and $46 \%$ in North America. It was reported that most of the HSIL cases in Europe had HPV type 16, whereas only $10 \%$ had HPV type 31, 8.6\% had HPV 33, 6\% had HPV type $18,3.6 \%$ had HPV type 52 and $3 \%$ had HPV type 51 (11).

Briolat et al. included women with high risk HPV infections (varied from ASC-US to HSIL) for determining high-risk HPV type prevalence especially HPV type 16 presences in single/multiple HPV infections in France. Pap smear test result was classified according to Bethesda system; HPV DNA was searched in total 363 cervical smear samples with 24 cases without any lesions, 96 CIN-I, 92 CIN-II, 144 CINIII and 7 cancer cases. In $41.6 \%$ of women, at least one high risk HPV type presence was detected, moreover it has been shown that $46.8 \%$ of this cases had HPV type 16 which was predominant and its prevalence increased with the severity of lesions ( for CIN-I 27.1\%; for CIN-III 65.3\%). In addition, it had been shown that the frequency of single infections, compared with multiple infections, increased with the severity of the lesion (CIN1: 25.0\%; CIN3: 54.8\%). As a result study showed that the importance of single versus multiple infections linked to the severity of CIN (12).

Szostek et al. reported that in a study which included 125 women from Poland ( 44 LSIL, 12 HSIL, 27 cervical carcinoma and 42 women without abnormality in cytology) HPV DNA was detected in $72 \%$ cases, more frequently in women with cervical carcinoma and squamous intraepithelial lesions than in the control group $(\mathrm{P}<0.0005)$. In the study, among the women with abnormal cytology, HPV DNA was positive in
$100 \%$ of the cervical cancers, $92 \%$ of HSIL cases and $98 \%$ of LSIL cases, also $21 \%$ of the women with normal cytology were HPV DNA positive. Out of HPV DNA positives, 37\% had HPV type 16. HPV type 16 prevalence was increased in the abnormal cervical cytology cases; $9 \%$ of the LSIL cases, $58.3 \%$ of the HSIL cases and $81.5 \%$ of cervical cancer cases, HPV type 16 DNA positivity was detected(13).

In a study that included 102 colposcopy suggested women, Dinç et al. reported $19.6 \%$ of the cases had total HPV DNA and $11 \%$ had HPV type 16 DNA. $30 \%$ of the colposcopy positive patients had total HPV positivity whereas $18 \%$ of them had HPV type 16 DNA and $12 \%$ had other types of HPV DNA. 9.5\% of the colposcopy negative patients had total HPV DNA positivity, moreover $3.8 \%$ of the positive cases had HPV type 16 DNA positivity and 5.7\% had other types of HPV DNA. In this study there was a statistically significant difference between colposcopy positive and colposcopy negative patients comparing total HPV with HPV Type 16 positivity ( $\mathrm{p}=0.010$ and $\mathrm{p}=0.021$ respectively $)^{(10)}$.

Yüce et al. reported a study on 890 women who came to hospital for routine gynocologic controls. $25.7 \%$ of the cases had HPV DNA positivity. Furthermore $89.5 \%$ of HPV positive women had at least one type of highrisk HPV and HPV type 16 was the most common genotype. According to the hospital based data, cervical infection with any HPV type infection is a serious and a gradually growing health problem for Turkish women. They also reported that this result could be associated with low age at marriage and more sensitive HPV detection methods ${ }^{(14)}$.

Turkish Cervical Cancer And Cervical Cytology Research Group had conducted a retrospective study for determining prevalence of cervical cytology abnormalities with the data from 33 health centers from Turkey. In 2007, 140.334 women that had Pap smear tests in health centers were evaluated for cervical cytology abnormalities and demographic features. In general the prevalence of cervical cytological abnormalities was reported as $1.8 \%$ and prevalence of ASC-US, ASC-H, LSIL, HSIL and AGC were 1.07\%, $0.07 \%, 0.3 \%, 0.17 \%$ and $0.08 \%$ respectively. The prevalence of preinvasive cervical neoplasia was $1.7 \%$ and the prevalence of cytologically diagnosed invasive neoplasia was $0.06 \%$.As a result, The abnormal cervical cytological prevalence rate in Turkey was found to be 
lower than in Europe and North America. They concluded that this result might be due to socio-cultural differences, lack of population-based screening programs, or a lower HPV prevalence rate in Turkey (15).

In a study done by Ergünay et al. HPV type distribution was searched on 35 cases with cytological abnormality detected in cervical smear samples. Nested Real-Time PCR was used for determination of HPV DNA. In cytological evaluation, women with 14 ASC-US, 3 ASC-H, 5 HSIL, 7 LSIL, 4 LSIL + suspicious HSIL, 1 AG-US and 1 unidentified natural atypical cell were included. HPV positivity was found $80 \%$ of the cases and the most predominant one was HPV type 16 in $50 \%$ of the cases. HPV 18 was found in $10.7 \%$ and HPV 53 in $7.1 \%$. As a result although the sample size was low, this study provided important results for HPV type distribution; however more detailed studies are needed to enlighten the HPV infection epidemiology in $\operatorname{Turkey}{ }^{(16)}$.

In our study, HPV prevalence in total patients was $21.6 \%$ and HPV type 16 prevalence was $10 \%$. According to our results $46.1 \%$ of HPV positive women had HPV type 16. A study done in another country Briolat et al reported $46.8 \%$ of HPV DNA positive women had HPV type 16 DNA which was the predominant type and showed similar results with our findings. In our study, among the patients with positive colposcopic findings $30 \%$ of the cases had HPV positivity and $44.4 \%$ of them had HPV type 16 .

In domestic studies HPV and HPV type 16 prevalence in positive cases were $19.6 \%$ and $55 \%$ for Dinç et al.,; $25.7 \%$ and $46.3 \%$ for Yüce et al. respectively and showed parallel results with our findings. In accordance with other researches, in our study HPV type 16 was found to be the most common infection factor. $30 \%$ of the patients with positive colposcopic findings had HPV positivity and $44.4 \%$ had HPV type 16 and 55.5\% had other types of HPV. Among the patient with negative colposcopic findings $13.3 \%$ had HPV positivity and $50 \%$ of the cases had HPV type 16 and $50 \%$ had other types of HPV. Our findings are highly correlated with the results that Dinç et al. reported. Presence of HPV DNA in women with negative colposcopic findings can be explained both due to HPV infection can be seen in women with normal cytological findings and $50-80 \%$ of the sexually active people are at least once infected with HPV during their lifespan (in addition 50\% of those had oncogenic HPV type). The prevalence that was reported in other domestic studies like our study is quite higher than the prevalence that is reported in other countries. We think that this situation can be explained due to hospital based studies, lack of screening programs and social differences in our country.

Patients were classified in two groups due to Pap smear test result as normal or abnormal cervical cytology. In 43 patients (54\%) that had abnormal cervical cytology, $30.2 \%$ of them was HPV positive and $54 \%$ of these positive patients had HPV type 16 and $46 \%$ had other types of HPV. Out of 37 (46\%) patients that had normal cervical cytology, $18.9 \%$ was HPV positive, $43 \%$ of these patients had HPV type 16 and $57 \%$ of them had other types of HPV. Pap smear test result was compared with HPV and HPV type 16 positivity and no statistically meaningful difference was found.

Independent factors such as the person that had applied Pap smear test, how smear sample was obtained, how the samples were prepared and evaluated, other inflammations unrelated to HPV infection, not only affect the reliability of outcomes but also cause false negativity and positivity which is a quite high ratio. In our findings although $50 \%$ of the patients had abnormal cytology, HPV infection ratio was $30.2 \%$. This situation can be explained by false negativity and positivity. We think that a molecular diagnostic method confirmation of Pap smear test will increase the reliability of the results.

Szostek et al. determined that $72 \%$ of women with abnormal cervical cytology, HPV DNA was positive and $37 \%$ of those had HPV type $16.92 \%$ of the HSIL cases and $98 \%$ of the LSIL cases were HPV DNA positive whereas $21 \%$ of the women with normal cytology were HPV DNA positive. $9 \%$ of the LSIL cases and $58.3 \%$ of the HSIL cases had HPV type 16 DNA. Briolat et al. had determined $46.8 \%$ of the women with abnormal cervical cytology which is varied from ASC-US to HSIL, had HPV type 16 DNA. Bosh et al. reported HPV type 16 prevalence in HSIL cases was $51.8 \%$ in Europe $33.7 \%$ in Asia and $46 \%$ in North America. In our findings, HPV DNA presence (30.2\%) was lower whereas HPV type 16 DNA positivity (54\%) was higher than the results of Szostek et al.. Again in our findings, HPV DNA presence in HSIL and LSIL cases was lower than the results reported by Szostek et al., on the other hand, similar HPV prevalence was 
reported in women with normal cytology. In addition, HPV type 16 prevalence that is responsible for LSIL was higher and HPV type 16 prevalence that is responsible for HSIL was considerably similar. In our study $54 \%$ of the women with abnormal cervical cytology had HPV type 16 DNA and this ratio is highly correlated with the prevalence that was reported by Briolat et al. According to our results, HPV type 16 prevalence was $57.1 \%$ in HSIL and this ratio is similar to prevalence that Bosch et al. reported for Europe, whereas higher than Asia and America. We conclude that this difference is due to dissimilarity of our socio-cultural structures with other countries. Moreover the differences in the prevalence could occur due to how and when the samples were collected and how they were preserved. In addition methods that were used to determine HPV DNA positivity could also cause prevalence differences. We believe that low case number also affected our outcomes in this study.

Turkish Cervical Cancer And Cervical Cytology Research Group reported prevalence of cervical cytological abnormalities as $1.8 \%$ and prevalence of ASC-US, ASC-H, LSIL, HSIL and AGC were reported to be $1.07 \%, 0.07 \%, 0.3 \%, 0.17 \%$ and $0.08 \%$ respectively. Ergünay et al. reported that HPV positivity in women with abnormal cytology was $80 \%$ and HPV type 16 was responsible for $50 \%$ of those cases. Due to our findings abnormal cervical cytology prevalence (54\%) and prevalence of ASC-US, ASC-H, LSIL, HSIL and AGC (48.8\%, 25.5\%, 13.9\%, 9.3\% and 2.3\% respectively) were higher than the results of Turkish Cervical Cancer And Cervical Cytology Research Group. We think that these findings resulted from that our study was a hospital based research. According to our results, although the HPV prevalence (30.2\%) that was detected in cases with abnormal cervical cytology was lower than the result of Ergünay et al.'s rates, HPV type 16 prevalence in these women was quite similar. Difference in our findings can be due to wrong interpretation of the Pap smear test results or inattention to smear taking process.

A meta-analysis study done by Sanjosé et al. determined probable age and genotype-specific prevalence of HPV in women with normal cervical cytology worldwide. Overall HPV prevalence in 157879 women with normal cervical cytology was estimated to be $10.4 \%$ (95\% CI (confidence Interval) 10.2-10.7). Corresponding estimates by region were found to be $22.1 \%$ (20.9-23.4) in Africa,
20.4\% (19.3-21.4) in Central America and Mexico, $11.3 \%$ (10.6-12.1) in Central America and Mexico, 8.1\% (7.8-8.4) in Europe, and 8.0\% (7.5-8.4) in Asia. In all world regions, HPV prevalence was highest in women younger than 35 years of age, incline to decrease in women of older than 35 years age. In Africa, America, and Europe, a clear second peak of HPV prevalence was observed in women aged 45 years or older. On the basis of these estimates, they reported that around 291 million women worldwide were carriers of HPV DNA, of whom $32 \%$ were infected with HPV16 or HPV 18 , or both. The most common HPV types were HPV type 16, HPV type 18, HPV type 31, HPV type 58 and HPV type $52^{(17)}$.

In a study in France, Vaucel et al. detected HPV DNA presence in $21 \%$ of the women. When women were grouped according to their ages $44 \%$ of the women aged 20 or below had HPV DNA infection and the highest prevalence were observed in this group. The prevalence decreased with increasing age reaching about $10 \%$ above 35 years $(\mathrm{p}<0.001)$. High-risk genotype was found in $24 \%$ in women below 25 years of age and $6.5 \%$ in women over 25 years. Mean age for LSIL and HSIL were 32 and 38.5(18).

Usubütün et al. detected HPV DNA in $93.5 \%$ of the invasive cervical cancer specimens. In addition HPV type 16 were responsible from $64.7 \%$ of those. Multivariate analysis relation between age and histology was studied for HPV type 16 and compared to squamous cell carcinoma, adenocarcinoma had lower chance of having HPV type 16 positivity (Odds ratio: 0.2; \%95 CI: 0.1-0.6) with decreasing age (age 50 or below). This relation was not detected in women older than 50. (age 50; odds ratio: 1.3 ; \%95 CI: 0.3-5.0)(19).

80 Women with ages varied from 18 to 66 which were included in our study were classified in three groups according to their ages as 34 and below, 35-48 and 49 or over. In the first group which consist of cases aged 34 and below, out of 31 women, $25.8 \%$ of them was found to be HPV positive, $\% 50$ of the positive cases had HPV type 16 and 50\% had other types of HPV. In the second group which consists of cases aged 35$48,23.3 \%$ of 30 women found to be HPV positive and $43 \%$ of those had HPV type 16 and $57 \%$ of them had other types of HPV. In the third group which consists of cases aged 49 or above, $26.3 \%$ of 19 women was HPV positive and $60 \%$ of them had HPV type 16 and $43 \%$ of them had other types of HPV. In our study age 
was compared with HPV positivity and HPV type 16 presence, however no statistically significant result was found $(\chi 2=0.073, \mathrm{p}=0.964 ; \chi 2=0.364, \mathrm{p}=0.834$ $\chi 2=0.091, \mathrm{p}=0.955)$. Relation between HPV prevalence and age groups showed variability. Hence socio-cultural, economical and social value judgments of society can differ, same-aged people can exhibit different sexual behaviors. Thus, we think that prevalence is not directly related with age but also correlated with age-related sexual habits.

In a study, Guarisi et al. reported that smoking was not associated with the risk of developing CIN (Hazards Ratio $=0.73$; 95\% CI: 0.40-1.33). However, developing high-grade CIN only, the probability of developing the disease was significantly higher among smokers $(\mathrm{p}=0.04)$. Smoking contributes additional risk for developing high-grade CIN in women with ASC or LSIL cytology but normal colposcopy ${ }^{(20)}$.

Eroğlu et al. reported that $30.8 \%$ (95/308) of the nonsmoker women and $36.5 \%$ (35/96) of smoker women had HPV type 16 positivity, however there was no statistically significant difference found $(p=0.30)^{(3)}$. HPV was positive in all smoker patients (3) and smokers in our control group (2). Statistically significant difference cannot be found due to low number of smoker patients.

Studies of Liu et al. and Bell et al. had reported that increasing partner number increases the risk however, for every population, risk ratio was variable $(21,22)$. Domestic study by İnal et al. found out that women having more than 2 or more number of marriage and partner numbers, HPV prevalence were $6.9 \%$ and $3.4 \%$ respectively and increasing partner number increased HPV infection risk $(\mathrm{P}=0.05)^{(23)}$. In our study; $27.6 \%$ of the married and $18.2 \%$ of the single women had HPV DNA positivity. As partner number of the people cannot be interrogated, this phenomenon can explain the resulting ratio. We also think that sexual behaviors which are affected by socio-cultural structure of societies can explain this condition.

In a study done in Korea by Kim et al. for HPV infections, women that had 3 or more deliveries was faced with more increased risk when compared to women that had no delivery. (\%95 CI, 1,4-16,7) ${ }^{(24)}$.

In a study done by Dinç et al. women that had two or less delivery was compared with the women that had 3 or more delivery for HPV type 16, other HPV types (other than 16) and HPV DNA positivity. They have reported a statistically significant difference $(\mathrm{p}=0,037$; $\mathrm{p}<0.001 ; \mathrm{p}<0,001$ respectively). Prevalence was $40 \%$ for patients with 0-2 parity whereas it was $60 \%$ for patients with 3 or more parity. In addition it has been reported that high parity is an increased risk factor for HPV infections and cervical cancers ${ }^{(10)}$.

In our study, women with number of pregnancies 02, 3-5, 6-10 had prevalences $22.6 \%, 26.1 \%$, 50\% respectively. Number of pregnancies cannot be statistically compared with HPV and HPV type 16 positivity, however there was a statistically meaningful relationship between number of pregnancies and other HPV types $(\chi 2=6.835, p=0.033)$. In addition a proportional increase was detected between pregnancy number and total HPV positivity. Our study results were in accordance with the results of Kim et al. and Dinç et al.. In addition, we think there is a correlation between high parity with increased HPV infection risk. As a result detection of HPV which is assumed to be a major factor in cervical cancer etiology and especially highly oncogenic HPV type 16 carries a major importance. For this reason designing cervical cancer prevention programs that include protection against HPV infections are crucial. In our study, HPV and HPV type 16 prevelence was evaluated by Real-Time PCR, on women referred to our hospital with cervical complaints and indicated for colposcopy. In addition there was no statistically significant result determined between cervical cancer risk factors such as Pap smear test result, age, marital status, tobacco use and HPV positivity. On the other hand, in accordance with the literature there was a statistically significant relation between parity and HPV infection. We think that Realtime PCR is a highly reliable method with low cost for investigating HPV DNA presence in women and should be used during planning an effective cervical cancer prevention program.

The women that are HPV positives or in the risk group should be followed in a specific algorithm and should be guided according to the results. 


\section{REFERENCES}

1. Arbyn, M, Castellsagué X, de Sanjosé S, Bruni L, Saraiya M, Bray F, et al. Worldwide burden of cervical cancer in 2008. Ann Oncol. 2011; 22: 2675- 86.

2. Castellsague X, de Sanjose S, Aguado T, et al. HPV and Cervical Cancer in The World, 2007 Report. WHO/ICO Information Centre on HPV and Cervical Cancer (HPV Information Centre). Geneva: WHO; Barcelona: ICO. http://www.who.int/hpvcentre/en/. Accessed January 6, 2010.

3. Eroğlu C, Keşli R, Eryılmaz MA, Ünlü Y, Gönenç O, Çelik Ç. Serviks kanseri için riski olan kadınlarda HPV tiplendirmesi ve HPV sıklığının risk faktörleri ve servikal smearle ilişkisi. Nobel Med. 2011; 7(3): 72- 7.

4. Güner H, Taşkıran Ç. Serviks kanseri epidemiyolojisi ve Human Papilloma virus. Türk Jinekoloji ve Obstetrik Derneği Dergisi 2007; 4: 11 - 9 .

5. Bernard, HU, Burk RD, Chen Z, van Doorslaer K, Hausen H, de Villiers EM. Classification of papillomaviruses (PVs) based on 189 PV types and proposal of taxonomic amendments. Virology. 2010; 401: 70- 9.

6. Cobo F, Concha Á, Ortiz M. Human Papillomavirus (HPV) Type Distribution in Females with Abnormal Cervical Cytology. A Correlation with Histological Study.The Open Virology Journal. 2009; 3: 60- 6.

7. Bayramov V, Şükür YE, Tezcan S. Anormal Pap smear sonucu yönetiminde kolposkopi, yüksek riskli HPV-DNA ve histopatolojik incelemenin önemi. Türk Jinekoloji ve Obstetrik Derneği Dergisi, (J Turk Soc Obstet Gynecol). 2011; 8(4): 272-80.

8. Ehehalt D, Lener B, Pircher H, Dreier K, Pfister H, Kaufmann AM, et al. Detection of Human Papillomavirus Type 18 E7 Oncoprotein in Cervical Smears: a Feasibility Study. J Clin Microbiol. 2012; 50(2): 246- 57.

9. Nishino HT, Tambouret RH and Wilbur DC. Testing for Human Papillomavirus in cervical cancer screening. Cancer Cytopathology. 2011; 119: 219- 27.

10. Dinc B, Rota S, Onan A, Bozdayi G, Taskiran C, Biri A, et al. Prevalence of HPV in colposcopy patients. Braz J Infect Dis. 2010; 14(1): 19- 23.

11. Bosch FX, Burchell AN, Schiffman M, Giuliano AR, de Sanjose S, Bruni L, et al. Epidemiology and natural history of Human Papillomavirus infections and type-specific implications in cervical neoplasia. Vaccine. 2008; 26(10): K1- 16.

12. Briolat J, Dalstein V, Saunier M, Joseph K, Caudroy S, Prétet JL, et al. HPV prevalence, viral load and physical state of HPV-16 in cervical smears of patients with different grades of CIN. Int J Cancer. 2007; 121(10): 2198- 204.

13. Szostek S, Klimek M, Zawilinska B, Kosz-Vnenchak M. Genotype-specific Human Papillomavirus detection in cervical smears. Acta Biochim Pol. 2008; 55(4): 687- 92.

14. Yüce K, Pinar A, Salman MC, Alp A, Sayal B, Dogan S, et al. Detection and genotyping of cervical HPV with simultaneous cervical cytology in Turkish women: a hospital-based study. Arch Gynecol Obstet. 2012.

15. Ayhan A, Dursun P, Kuşçu E, Mülayim B, Haberal N, Ozen O, et al. Turkish Cervical Cancer And Cervical Cytology Research Group. Prevalence of cervical cytological abnormalities in Turkey. Int J Gynaecol Obstet. 2009; 106(3): 206- 9 .

16. Ergünay K, Mısırlıglu M, Firat P, et al. Sitolojik olarak anomali saptanan serviks örneklerinde insan Papilloma virus DNA'sının araştırılması ve virusun tiplendirilmesi. Mikrobiyol Bült. 2007; 41: 219- 26.

17. de Sanjosé S, Diaz M, Castellsagué X, Clifford G, Bruni L, Muñoz N, et al: Worldwide prevalence and genotype distribution of cervical human papillomavirus DNA in women with normalcytology: a meta-analysis. Lancet Infect Dis . 2007; 7(7): 453- 9.

18. Vaucel E., Coste-Burel M., Laboisse C., Dahlab A., Lopes P. Human Papillomavirus genotype distribution in cervical samples collected in routine clinical practice at the Nantes University Hospital, France. Arch Gynecol Obstet. 2011; 284 : 989- 98.

19. Usubütün A, Alemany L, Küçükali T, Ayhan A, Yüce K, de Sanjosé S, et al. Human Papillomavirus types in invasive cervical cancer specimens from Turkey. Int J Gynecol Pathol. 2009; 28(6): $541-8$.

20. Guarisi R, Sarian LO, Hammes LS, Longatto-Filho A, Derchain SF, Roteli-Martins C, et al. Smoking worsens the prognosis of mild abnormalities in cervical cytology. Acta Obstet Gynecol Scand. 2009; 88(5): 514- 20.

21. Liu SS, Chan KYK, Leung RCL, Chan KKL, Tam KF, Luk MHM., et al. Prevalence and Risk Factors of Human Papillomavirus (HPV) Infection in Southern Chinese WomenA Population-Based Study, Journal.pone. 2011; 6(5): e19244.

22. Bell MC, Schmidt-Grimminger D, Jacobsen C, Chauhan SC, Maher DM, Buchwald DS, Risk factors for HPV infection among American Indian and white women in the Northern Plains. Gynecologic Oncology. 2011; 121; 532- 6.

23. Inal MM, Köse S, Yildirim Y, Ozdemir Y, Töz E, Ertopçu $\mathrm{K}$, et al. The relationship between human papillomavirus infection and cervical intraepithelial neoplasia in Turkish women. Int J Gynecol Cancer. 2007; 17(6): 1266- 70. 
Diagnosing human papillomavirus and human papilloma virus type 16 by realtime PCR in patient undergone to colposcopy and significance of the diagnosis

24. Kim CJ, Lee YS, Kwack HS, Yoon WS, Park TC, Park JS. Specific human papillomavirus types and other factors on the risk of cervical intraepithelial neoplasia: a case-control study in Korea. Int J Gynecol Cancer. 2010 Aug; 20(6): 1067- 73. 